\title{
S100B sebagai Prediktor Defisit Neurologi pada Anak dengan Sepsis
}

Jati Kusuma Wardhani, Tjipta Bahtera

Bagian Ilmu Kesehatan Anak Fakultas Kedokteran Universitas Diponegoro/RSUP Dr. Kariadi, Semarang

Latar belakang. Respon sepsis merupakan rantai kejadian yang kompleks, terdiri dari proses inflamasi dan anti inflamasi, reaksi humoral dan selular, dan abnormalitas hemodinamik. Komplikasi sepsis dapat terjadi di semua organ dengan manifestasi berupa kegagalan fungsi multiorgan, salah satunya adalah susunan saraf pusat. Biomarker S100B merupakan suatu pemeriksaan yang digunakan untuk mengetahui tingkat kerusakan neurologi dan prognosis pasien anak/bayi dengan kondisi kritis salah satunya adalah sepsis

Tujuan. Membuktikan bahwa kadar S100B dapat digunakan sebagai prediktor terjadinya defisit neurologi pada anak dengan sepsis. Metode. Penelitian kohort prospektif pada 52 pasien anak dengan sepsis yang dirawat di Bangsal Anak, HCU, PICU dan IGD RSUP Dr. Kariadi Semarang periode Januari 2019 sampai Juni 2019. Pasien dengan sepsis diambil sampel darah S100B untuk dinilai kemudian dilihat dalam waktu 3 hari ada atau tidaknya defisit neurologi. Perbedaan S100B antara kedua kelompok dianalisis dengan uji Independent T Test. Cut-off point serum S100B sebagai prediktor defisit neurologi ditentukan dengan menggunakan kurva ROC. Hasil. Sejumlah 52 anak sepsis diikutkan dalam penelitian. Terdapat 20 anak dengan defisit neurologi dan 32 anak tanpa defisit neurologi. Mean S100B dengan defisit neurologi adalah $0,44 \pm 0,24 \mu \mathrm{g} / \mathrm{L}$ dan tanpa defisit neurologi adalah $0,14 \pm 0,06 \mu \mathrm{g} / \mathrm{L}(95 \%$ CI 0,21-0,39, p<0,0001). Luas area di bawah kurva ROC 0,923, dengan cut-off point S100B 0,21 $\mu \mathrm{g} / \mathrm{L}$, RR 9,84 (95\% CI 3,30929,27; $\mathrm{p}<0,0001)$.

Kesimpulan. S100B dapat digunakan sebagai prediktor defisit neurologi pada anak dengan sepsis. Sari Pediatri 2020;22(4):218-23

Kata kunci: S100B, sepsis, defisit neurologi, prediktor

\section{S100B as Predictor of Neurological Deficit in Children with Sepsis}

Jati Kusuma Wardhani, Tjipta Bahtera

Background. Sepsis response is a complex chain of events, consisting of inflammatory and anti-inflammatory processes, humoral and cellular reactions, and hemodynamic abnormalities. Sepsis complications can occur in all organs with manifestations in the form of multiorgan failure, one of which is the central nervous system. Biomarker S100B is an examination used to determine the level of neurological damage and prognosis of pediatric / infant patients with critical conditions, one of which is sepsis.

Objective. To prove that $\mathrm{S} 100 \mathrm{~B}$ levels can be used as predictors of neurological deficits in children with sepsis.

Methods. A prospective cohort study of 52 pediatric patients with sepsis treated in the Children's Ward, HCU, PICU and IGD at RSUP Dr. Kariadi Semarang for January 2019 until June 2019. Patients with sepsis were taken as S100B blood samples to be assessed and then seen within 3 days of the presence or absence of neurological deficits. The difference in the S100B between the two groups was analyzed by the Independent T Test. Serum S100B cut-off point as a predictor of neurological deficit was determined using the ROC curve.

Result. A total of 52 sepsis children were included in the study. There were 20 children with neurological deficits and 32 children without neurological deficits. The mean $\mathrm{S} 100 \mathrm{~B}$ with a neurological deficit was $0.44 \pm 0,24 \mu \mathrm{g} / \mathrm{L}$ and without neurological deficit was $0.14 \pm 0,06 \mu \mathrm{g} / \mathrm{L}(95 \% \mathrm{CI} 0,21-0,39, \mathrm{p}<0.0001)$. The area under the ROC curve is 0.923 , with the S100B cut-off point $0.21 \mu \mathrm{g} / \mathrm{L}$, RR 9.84 (95\% CI $3.309-29.27$; $<<0,0001)$.

Conclusion. S100B can be used as a predictor of neurological deficits in children with sepsis. Sari Pediatri 2020;22(4):218-23

Keywords: S100B, sepsis, neurological deficit, predictor

Alamat korespondensi: Jati Kusuma Wardhani. Bagian Ilmu Kesehatan Anak Fakultas Kedokteran UNDIP/RSUP Dr Kariadi, Jl. Dr. Sutomo No16-18, Semarang. Email: ikarsdk@gmail.com 
S epsis merupakan penyebab utama kematian pada anak di seluruh dunia. ${ }^{1,2}$ Angka kejadian dan kematian yang tinggi, tatalaksana yang rumit, mortalitas yang tinggi dan biaya perawatan yang mahal mengakibatkan sepsis menjadi masalah global di berbagai negara berkembang maupun negara maju. ${ }^{3}$ Di unit perawatan intensif anak Rumah Sakit Cipto Mangunkusumo (RSCM), 19,3\% dari 502 pasien anak yang dirawat mengalami sepsis dengan angka mortalitas 54\%. ${ }^{4}$ Komplikasi sepsis dapat terjadi di semua organ, salah satunya adalah susunan saraf pusat yang rentan terhadap gangguan sistemik. Ensefalopati sepsis adalah salah satu manifestasi yang sering ditemukan, dengan prevalensi antara $9-71 \%$. 4-6 Terdapat beberapa cara yang bisa dilakukan untuk memprediksi terjadinya hipoksi iskemik otak pada sepsis. ${ }^{7}$ Pada hipoksia otak, banyak marker biokimia yang akan ditemukan dalam serum, tetapi terdapat beberapa marker yang spesifik dan sensitif terhadap kejadian defisit neurologi salah satunya adalah protein S100B. Biomarker S100B merupakan alternatif pemeriksaan yang digunakan untuk mengetahui tingkat kerusakan neurologi dan prognosis pasien anak/bayi dengan kondisi kritis (critically ill). Protein S100B merupakan peptide yang berikatan dengan kalsium yang dihasilkan terutama oleh astrosit dengan menggunakan efek autokrin dan parakrin terhadap neuron dan sel glia. ${ }^{8-11}$

Diagnosis awal dan stratifikasi tingkat keparahan sepsis yang berhubungan dengan system saraf pusat merupakan hal yang penting, yang dapat meningkatkan kemungkinan terapi spesifik sehingga dapat menghasilkan luaran yang lebih baik. Penelitian ini ditujukan untuk mengetahui apakah terdapat hubungan antara kadar S100B dengan defisit neurologi pada anak dengan sepsis.

\section{Metode}

Penelitian kohort prospektif dilakukan dari Januari 2019 hingga Juni 2019 pada anak sepsis usia 2-18 tahun yang bersekolah di Semarang. Subjek sejumlah 52 anak yg memenuhi kriteria penelitian dengan pengumpulan sampel secara consecutive, terdiri dari 20 anak dengan defisit neurologi dan 32 anak tanpa defisit neurologi. Kriteria inklusi adalah anak usia (usia 2-18 tahun) yang mengalami sepsis yang dirawat di RSUP Dr. Kariadi
Semarang. Penentuan sepsis sesuai dengan kriteria sepsis berdasarkan Konsensus Internasional Sepsis Pediatrik tahun 2016. Kriteria eksklusi adalah anak yang mengalami cedera neurologi primer sebelumnya (cedera kepala, epilepsi, infeksi intrakranial, tumor serebri), anak yang mengalami cedera neurologi sekunder (ensefalopati hepatikum, ensefalopati dengue, hipertensi ensefalopati, hiponatremi, ketoasidosis diabetikum, hipoglikemia), pasien dengan kelainan jantung, pasca bedah jantung yang mendapat terapi, pasien yang berada pada kondisi sedasi, orang tua menolak untuk diambil sampel penelitian. Informed consent diberikan kepada pasien (bila telah mengerti), serta orangtua atau keluarga mengenai penelitian yang akan dilakukan. Seluruh subjek yang datang ke RSUP Dr. Kariadi dalam waktu 24 jam setelah awitan sepsis diambil sampel serum S100B kemudian diikuti selama 3 hari untuk menentukan ada tidaknya defisit neurologi.

Darah vena sebanyak $5 \mathrm{ml}$ diambil sebagai bagian dari penelitian. Darah vena $5 \mathrm{ml}$ tersebut disentrifuge dengan kecepatan $3000 \mathrm{rpm}$ selama 15 menit, kemudian serum yang terbentuk dipisahkan dan disimpan di freezer pada suhu $-20^{\circ} \mathrm{C}$. Pemeriksaan S100B diukur dengan ELISA ( Biorad ELISA READER 680).

Analisis statistik digunakan untuk membandingkan nilai S100B pada anak sepsis dengan defisit neurologi dan tanpa defisit neurologi. Perbedaan dianggap bermakna apabila $\mathrm{p}<0,05$. Analisis kurva ROC dilakukan untuk mengetahui nilai cut-off-point kadar S100B. Analisis data menggunakan program SPSS for Windows v.15.0. Persetujuan etik (ethical clearance) didapat dari dari Komisi Etika Penelitian Kedokteran Fakultas edokteran Universitas Diponegoro/RSUP Dr Kariadi Semarang.

\section{Hasil}

Penelitian dilakukan di RSUP Kariadi Semarang, mulai bulan Januari 2019 hingga bulan Juni 2019 pada 52 subyek anak yang sesuai dengan kriteria inklusi dan eksklusi.

Karakteristik subyek penelitian ditampilkan pada tabel 1. Tidak terdapat perbedaan bermakna antara kelompok subyek dengan defisit neurologi dan tanda defisit neurologi dalam hal umur, jenis kelamin, 


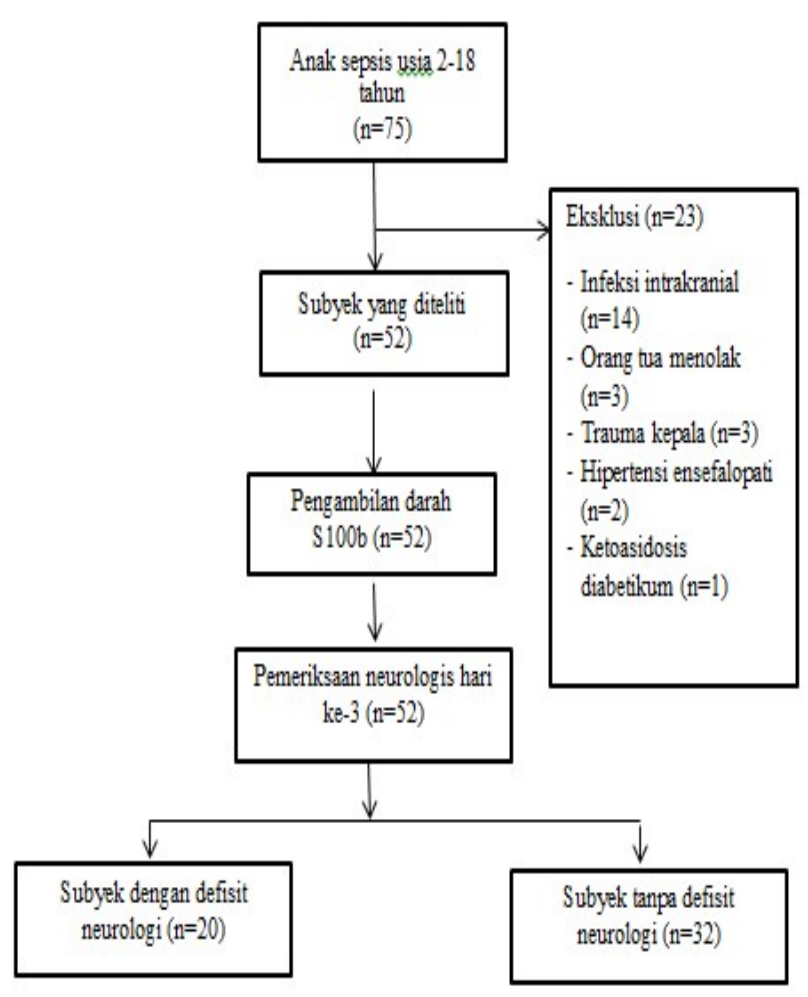

Gambar 1. Subyek penelitian

pemberian antibiotik, status gizi, jumlah leukosit dengan nilai $p>0,05$. Hal ini dapat menunjukkan bahwa subyek homogen sehingga faktor tersebut tidak memengaruhi luaran defisit neurologi pada masingmasing kelompok. Tabel 2 menunjukkan bahwa S100B

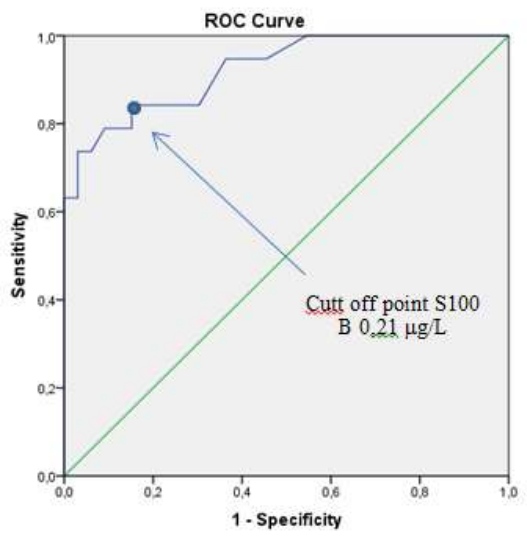

Gambar 2. Kurva ROC S100B sebagai prediktor defisit neurologi pada anak dengan sepsis

pada kelompok sepsis dengan defisit neurologi lebih tinggi secara bermakna dibandingkan kelompok tanpa defisit neurologi $(\mathrm{p}<0,05)$.

Analisis ROC S100B sebagai prediktor defisit neurologi pada anak dengan sepsis dapat dilihat pada gambar 2. Kurva ROC dibuat untuk mengetahui nilai prediksi kadar protein $\mathrm{S} 100 \mathrm{~B}$ dengan defisit neurologi, menghasilkan AUC 92,3\% dengan $\mathrm{p}<0,0001$, CI 95\% 0,859-0,998. Cut off point yang digunakan adalah 0,21 $\mu \mathrm{g} / \mathrm{L}$ dengan sensitifitas $84,2 \%$ dan spesifisitas $84,8 \%$, NRP (nilai ramal positif) 89,4\%, dan NRN (nilai ramal negatif) $90,9 \%$. Risiko relatif (RR) kelompok terpapar $\mathrm{S} 100 \mathrm{~B} \geq 0,21 \mu \mathrm{g} / \mathrm{L}$ untuk mengalami defisit neurologi sebesar $\mathrm{RR}=9,84$; IK95\%=3,309-29,27

Tabel 1. Karakteristik subyek

\begin{tabular}{lccc}
\hline \multirow{2}{*}{ Variabel } & \multicolumn{2}{c}{ Defisit neurologi } & \multirow{2}{*}{$\mathrm{p}$} \\
\cline { 2 - 3 } & Ada $(\mathrm{n}=20)$ & Tidak ada $(\mathrm{n}=32)$ & $0,372^{\ddagger}$ \\
Umur (tahun), median & $5(3-15)$ & $6(2-14)$ & \\
Jenis kelamin, n (\%) & & & \\
$\quad$ Laki-laki & $9(45)$ & $15(46,9)$ & $1,0^{€}$ \\
$\quad$ Perempuan & $11(55)$ & $17(53,1)$ & \\
Status gizi, n (\%) & & & \\
$\quad$ Malnutrisi & $16(80)$ & $22(68,8)$ & $0,570^{\epsilon}$ \\
$\quad$ Tidak malnutrisi & $4(20)$ & $10(31,3)$ & \\
Antibitiok n (\%) & & & \\
$\quad$ Diberikan & $16(80)$ & $24(75)$ & $0,938^{€}$ \\
$\quad$ Tidak diberikan & $4(20)$ & $8(25)$ & \\
Leukosit $\left(10^{3} / \mathrm{mm}^{3}\right)$, median & $19,2(14,7-31,2)$ & $17,7(2,1-34,3)$ & $0,279^{\ddagger}$ \\
\hline Ke
\end{tabular}

Keterangan : ${ }^{\ddagger}$ Mann Whitney $\mathrm{U} ;{ }^{\circledR}$ chi square 
Jati Kusuma Wardhani dkk: S100B sebagai prediktor defisit neurologi pada anak dengan sepsis

Tabel 2. Perbedaan kadar S100B berdasarkan ada tidaknya defisit neurologi

\begin{tabular}{llcc}
\hline \multicolumn{4}{c}{ Defisit neurologi } \\
\hline Variabel & Ada $(20)$ & Tidak ada $(32)$ & CI $95 \%$ \\
\hline S100B $($ mean \pm SB) & $0,44 \pm 0,24$ & $0,14 \pm 0,06<0,0001^{\vee} 0,21-0,39$ & Keterangan : ${ }^{\vee}$ Independent T Test
\end{tabular}

Tabel 3. Perbedaan S100B di atas dan di bawah cut off point terhadap ada tidaknya defisit neurologi

\begin{tabular}{|c|c|c|c|c|c|}
\hline S100B & \multicolumn{2}{|c|}{ Defisit neurologi } & $\mathrm{p}$ & $\mathrm{RR}$ & CI 95\% \\
\hline & $\operatorname{Ada}(20)$ & Tidak (32) & & & \\
\hline$\geq 0,21 ; \mathrm{n}(\%)$ & $17(85)$ & $2(6,25)$ & $<0,0001^{\epsilon}$ & 9,84 & $3,309-29,27$ \\
\hline$<0,21 ; \mathrm{n}(\%)$ & $3(15)$ & $30(93,75)$ & & & \\
\hline
\end{tabular}

dengan nilai $\mathrm{p}<0,0001$. Hal ini menunjukkan bahwa nilai $\mathrm{S} 100 \mathrm{~B}>0,21 \mu \mathrm{g} / \mathrm{L}$ meningkatkan risiko defisit neurologi sebesar 9,84 kali (Tabel 3).

\section{Pembahasan}

Ensefalopati sepsis merupakan komplikasi sepsis yang paling sering terjadi. Manifestasi neurologis pada pasien dengan sepsis umumnya berupa penurunan kesadaran, kejang, parase, berkurangnya memori, disorientasi, gangguan fungsi kortikal dan kematian yang dapat dinilai secara klinis dan dikaitkan dengan ensefalopati sepsis. Secara klinis, tanda dan gejala awal terjadinya gangguan otak pada pasien sepsis dapat terjadi saaat tahap awal dan sering terjadi sebelum adanya kerusakan organ lainnya. Pada kasus yang lebih berat dapat menimbulkan delirium, agitasi dan deteriorasi kesadaran dan koma. ${ }^{12}$ Kejang juga dapat timbul pada ensefalopati septik, tetapi tidak umum, disfungsi saraf kranial dan lateralisasi jarang terjadi dan harus dapat menyingkirkan penyebab lain yang mungkin. ${ }^{13,14}$ Prevalensi ensefelaopati sepsis pada berbagai studi adalah 9-71\%., Sejalan dengan penelitan ini, ditemukan gejala sepsis ensefalopati secara klinis pada sepsis hari ketiga sebanyak $20(38,46$ $\%)$ subyek.

Protein S100B utamanya dihasilkan oleh astrosit di susunan saraf pusat (SSP) dan menunjukkan aktivasi astrosit. Kadar protein S100B intra atau ekstraseluler dan mRNA telah digunakan sebagai parameter aktivasi dan/atau kematian astrosit pada beberapa kondisi cedera otak. Peningkatan kadar S100B di serum atau CSF berhubungan dengan berbagai gangguan yang memengaruhi SSP. ${ }^{17}$ Analisis ROC pada penelitian dilakukan untuk menentukan titik potong kadar S100B serum yang berkesesuaian dengan defisit neurologi. Untuk keperluan prediktor, maka dipilih titik potong dengan sensitivitas tinggi, yaitu pada kadar $0,21 \mu \mathrm{g} / \mathrm{L}$ dengan sensitifitas $84,2 \%$ dan spesifisitas $84,8 \%$ Risiko relatif (RR) kelompok terpapar penelitian ini dengan cut off point $\mathrm{S} 100 \mathrm{~B} \geq$ $0,21 \mu \mathrm{g} / \mathrm{L}$ untuk mengalami defisit neurologi adalah 9,84. Hal ini berbeda dengan penelitian Arifin ${ }^{18}$ yang melaporkan bahwa kurva ROC yang dibuat untuk mengetahui nilai prediksi kadar protein S100B dengan perbaikan/perburukan kesadaran dengan nilai ambang skor GCS kurang dari 12, menghasilkan nilai ambang $0,03 \mu \mathrm{g} / \mathrm{L}$ dengan sensitifitas $38,5 \%$ dan spesifisitas $94,1 \%$. Penelitian tersebut mendapatkan nilai $\mathrm{p}>0,05$, bias pengukuran dalam kurva ROC untuk S100B dinilai cukup besar atau tidak signifikan. Diduga kendala teknis berupa pengadaan kit protein S-100B yang mendekati tanggal kadaluarsa. Penelitian ini juga tidak menyebutkan kapan waktu pengambilan S100B saat diagnosis sepsis ditegakkan.

Yao $\mathrm{dkk}^{19}$ meneliti tentang S100B sebagai penentu prognosis dalam ensefalopati sepsis. Penelitian ini mendapatkan nilai cut offpointsebesar $0,131 \mu \mathrm{g} / \mathrm{L}$ dengan spesifisitas $67,2 \%$ dan sensitifitas $85,4 \%$. Pemeriksaan S100B penelitian Yao berbeda dengan penelitian kami. Kami menggunakan metode ELISA dalam pemeriksaan S100B, sedangkan Yao menggunakan Roche cobas S100 (electrochemoluminometric immunoassay (Elecsys)). Selain itu, subjek pada penelitian tersebut tidak hanya anak, tetapi subjek dewasa juga masuk dalam penelitian ini. ${ }^{19}$ Hasil yang sama juga dijumpai pada 
penelitan Hamed ${ }^{17}$ yang menemukan nilai S100B pada pasien ensefalopati sepsis lebih tinggi dibandingkan pasien sepsis. Berbeda dengan penelitian kami, subjek penelitian Hamed adalah anak usia 0-15 tahun yang menderita sepsis atau sepsis berat dengan menggunakan kriteria dari American College of Chest Physicians/Society of Critical Care Medicine Consensus Conference tahun 1992.

S100B merupakan peptide yang berikatan dengan kalsium yang dihasilkan terutama oleh astrosit dengan menggunakan efek autokrin dan parakrin terhadap neuron dan glia. Peningkatan kadar S100B berhubungan dengan kejadian patologi atau keparahan klinis dalam bermacam gangguan yang memengaruhi SSP. Penelitian Hamed $\mathrm{dkk}^{17}$ menyimpulkan bahwa peningkatan kadar S100B di serum atau CSF berhubungan dengan berbagai gangguan yang memengaruhi SSP. ${ }^{17}$ Banyak penelitian melakukan pengukuran terhadap S100B pada pasien yang mengalami traumatic brain injury (TBI). Salah satunya adalah penelitian yang dilakukan oleh Nurmalia, ${ }^{20}$ untuk keperluan skrining trauma dipilih titik potong dengan sensitivitas tinggi, yaitu pada kadar $0,083 \mu \mathrm{g} / \mathrm{L}$ dengan sensitivitas $95 \%$ dan spesifitas $72 \%$. Berbeda dengan penelitian kami, penelitian Nurmalia menggunakan subjek anak dengan trauma kepala.

Kadar S100B berhubungan dengan kelanjutan kerusakan otak dan tingkat kesadaran rendah pada ensefalopati. Hal ini terlihat dalam penelitian Nguyen $\mathrm{dkk}^{21}$ yang melaporkan iskemia berat atau perdarahan yang terdokumentasi dalam CCT ditemukan pada subyek dengan kadar S100B $>4 \mu \mathrm{g} / \mathrm{L}$, sedangkan nilai antara 1 dan $2 \mu \mathrm{g} / \mathrm{L}$, lebih mungkin berhubungan dengan infark emboli multipel yang terdeteksi dengan MRI. Penurunan kesadaran pada ensefalopati lebih sering terlihat pada pasien dengan peningkatan S100B. S100B yang tinggi berhubungan dengan mortalitas ICU yang lebih tinggi. Nguyen juga melaporkan bahwa kematian otak didiagnosis pada pasien setelah 72 jam dari keadaan syok sepsis berat dengan nilai S100B meningkat, yaitu $4 \mu \mathrm{g} / \mathrm{L}$. Pemeriksaan S100B yang diambil 48-72 jam setelah kejadian stroke dapat memprediksi outcome fungsional dan volume infark pada infark arteri midlle serebri nonlakunar. Nilai S100B mencapai level puncak pada 3-4 hari setelah iskemik otak akut. Kedua penelitian ini berbeda dengan penelitian kami dimana menggunakan subjek orang dewasa dan pengambilan sampel adalah lebih dari 48 jam setelah terdiagnosis sepsis. ${ }^{22-25}$
Pengamatan pada penelitian ini didapatkan nilai S100B menurun sebanding dengan peningkatan usia, tetapi didapatkan 1 subyek berusia 3 tahun dengan kadar $0,97 \mu \mathrm{g} / \mathrm{L}$ yang menunjukkan luaran defisit neurologi berupa kematian. Rerata S100B subyek sepsis dengan defisit neurologi adalah $0,44 \pm 0,24 \mu \mathrm{g} / \mathrm{L}$, sedangkan rerata subyek sepsis tanpa defisit neurologi adalah $0,14 \pm 0,06 \mu \mathrm{g} / \mathrm{L}$. Terdapat perbedaan bermakna nilai S100B pada anak sepis dengan dan tanpa defisit neurologi. Hal ini serupa dengan penelitian Yao yang menemukan bahwa nilai S100B pada pasien sepsis ensefalopati lebih tinggi dibandingkan pada pasien tanpa sepsis ensefalopati. Penelitian Yao ${ }^{19}$ dalam hal ini berbeda dengan penelitian kami karena subjek yang diikutkan juga termasuk orang dewasa.

Dari penelitian ini dapat disimpulkan bahwa S100B lebih dari $0,21 \mu \mathrm{g} / \mathrm{L}$ menjadi prediktor terjadinya defisit neurologi pada anak sepsis. Dalam beberapa penelitian lainnya S100 B dapat digunakan untuk mengetahui derajat keparahan neurologi pada pasien trauma kepala, iskemia, ataupun perdarahan otak. Namun, subjek penelitiannya ada yang masih terbatas pada orang dewasa. Penelitian selanjutnya dapat digunakan untuk meneliti kondisi tersebut pada pasien anak.

\section{Daftar pustaka}

1. Hartman ME, Zwirble WT, Angus DC, Watson RS. Trends in he epidemiology of pediatric severe sepsis. Pediatr Crit Care Med 2013;14:686-93.

2. Dewi R. Sepsis pada Anak: Pola kuman dan uji kepekaan. Maj Kedokt Indon 2011;61:101-6.

3. Enrione MA, Powell KR. Sepsis, septic shock, and systemic inflammatory response syndrome. Nelson Textbook of Pediatrics. Edisi ke-19. Dalam: Kliegman RM, Behrman RE, Jenson HB, Stanton BF; penyunting. Philadelphia: Saunders Elsevier; 2011.h.1094-9.

4. Unit Kerja Koordinasi Emergensi dan Rawat Intensif Anak dan Unit Kerja Koordinasi Infeksi dan Penyakit tropik Ikatan Dokter Anak Indonesia. Konsensus diagnosis dan tata laksana sepsis pada anak. Jakarta: Badan Penerbit Ikatan Dokter Anak Indonesia; 2016.h.1-5.

5. Vincent JL, Opal SM, Marshall JC, Tracey KJ. Sepsis definitions: time for change. Lancet 2013;381:774-5.

6. Randolph AG, McCulloh RJ. Pediatric sepsis: Important considerations for diagnosing and managing severe infections in infants, children, and adolescents. Virulence 2014;5:179-89.

7. Cotena S, Piazza O. Sepsis-associated encephalopathy. Transl Med 2012;2:20-7.

8. Dellinger RP, Levy MM, Rhodes A, dkk. Surviving sepsis 
campaign : international guidelines for management of severe sepsis and septic shock : 2012. Crit Care Med 2013;41:1-61.

9. Singer M, Deutschman CS, Seymor CW, dkk. The third international consensus definitions for sepsis and septic shock (sepsis-3). JAMA 2016;315:801-10.

10. Remick DG. Pathophysiology of sepsis. Am J Pathol 2007; 170:1435-44.

11. Johnson D, Mayers I. Multiple organ dysfunction syndrome: a narrative review. Can J Anaesth 2001;20:502-8.

12. Sonnevile R, Verdonk F, Rauturier C, dkk. Understanding brain dysfunction in sepsis. Annals Intensive Care 2013;3:1-11.

13. Cotena S, Piazza O. Sepsis-Associated Encephalopathy. Transl Med 2012;2:20-27.

14. Ringer TM, Axer H, Romeike BF, dkk . Neurological Sequelae of sepsis : Septic Encephalopathy. The Open Crit Care Med J 2011;4:2-7.

15. Eidelman LA, Putterman D, Putterman C, Sprung CL. The spectrum of septic encephalopathy. Definitions, etiologies, and mortalities. JAMA 1996;275:470-3.

16. Sprung CL, Peduzzi PN, Shatney CH. Impact of encephalopathy on mortality in the sepsis syndrome. Critic Care Med 1990;18:801-6.

17. Hamed SA. Septic encephalopathy : relationship to serum and cerebrospinal fluid levels of adhesion molecules, lipid peroxidase and S100B protein. Neuropediatrics 2009;40:66-72.

18. Arifin N. Hubungan antara biomarker kerusakan otak dengan Glasgow Coma Scale dan manifestasi neurologis pada anak sepsis umur 2-18 tahun, tesis. Jakarta: Universitas Indonesia, 2011.

19. Yao Bo, Zhang LN, Ai YH, Liu ZY, Huang L. Serum S100B is a better biomarker than neuron spesific enolase for sepsisassociated encephalopathy and determining its prognosis: a prospective and observational study. Neurochem Res 2014; 39:1263-9.

20. Nurmalia LD. Peran S100B serum sebagai predictor derajat keparahan trauma kepala pada anak, tesis. Universitas Indonesia, 2016.

21. Nguyen DN, Spapen H, Su F, dkk. Elevated serum levels of S-100 beta protein and neuron-spesific enolase are associated with brain injury in patients with severe sepsis and septic shock. Crit Care Med 2006;34:1967-74.

22. Bouvier D, Castellani C, Fournier M, dkk. Reference ranges for serum S100B protein during the first three years of life. Clin Biochem 2011;44:927-9.

23. Zenaide PV, Flores DG. Biomarkers in septic encephalopathy: a systematic review of clinical studies. Rev Bras Ter Intensiva 2013;25:56-62.

24. Ringer TM, Axer H, Romeike BF, dkk . Neurological sequelae of sepsis : septic encephalopathy. The Open Crit Care Med J 2011;4:2-7.

25. Spinella PC, Dominguez T, Drott HR, dkk. S-100beta protein-serum levels in healthy children and its association with outcome in pediatric traumatic brain injury. Crit Care Med 2003;31:939-45. 